
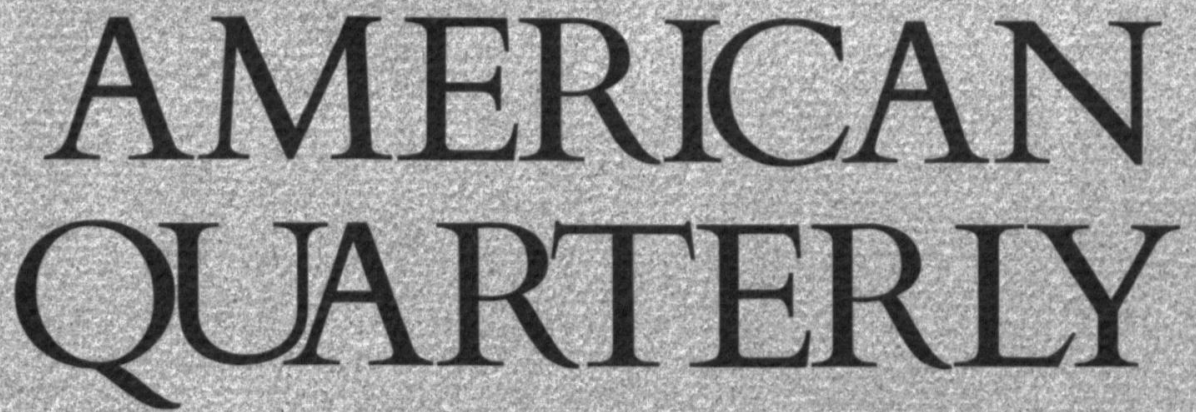

1

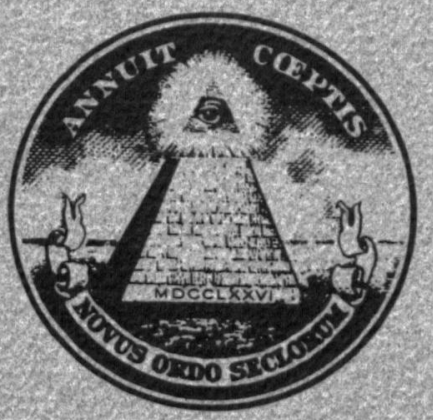

JUNE SOCHEN

PHYLLIS FRANKLIN

ROBERT CUFF

JEAN GORDON

JOHN L.CAUGHEY

FRANCHOT BALLINGER
MILDRED PIERCE

ENGLISH STUDIES IN AMERICA

HARRY GARFIELD AND THE FUEL ADMINISTRATION

EARLY AMERICAN WOMEN ARTISTS ARTIFICIAL SOCIAL RELATIONS

PUEBLO AND NAVAHO RITUAL SONGS 


\title{
SACRED CIRCLES: NATIVE AMERICAN ART AND AMERICAN CULTURE
}

\author{
STUART LEVINE \\ University of Kansas
}

Sacred Circles: Two Thousand Years of North American Indian Art was a large museum exhibit illustrating the artistic achievement of American Indian people north of Mexico. It was mounted twice, once in Great Britain as the major component of the commemoration of the United States Bicentennial, and once (from April 4 through June 19, 1977) at the Nelson Gallery of Art-Atkins Museum of Fine Arts in Kansas City, Missouri, the museum of which Ralph T. Coe, the organizer of the exhibit, is director.

Sacred Circles was designed to teach us about the beauty of Native American art work. The present essay is intended to discuss the show itself as an artifact. I mean to suggest that those in American Studies can make good use of such events because they reveal aspects of our values, our perceptions of reality, and the structure of our society; this show also reveals the remarkable persistence in the face of facts of certain long-lived misconceptions about American tribal peoples. We begin, then, by asking what can be learned from Sacred Circles about the way that North American Indian people are currently perceived.

Several of the basic assumptions and misunderstandings about Native American peoples were present before the first permanent European settlements in what are now the United States and Canada. The sixteenthcentury writings of Richard Hakluyt and George Peckham make this clear. The land, these Englishmen assumed, rightly belongs to the first modern Christian nation to stake a plausible claim to it. All "savages" behave in the same way. Leading them from their dark ways will not only be good for them and score points for us British in heaven, but will make our nation and especially the investors in such enterprises wealthy to boot. Such writers lumped Indian people together culturally and geographically, assuming, for instance, that all were subject to bloody sacrificial rites, 
uncertain future. Thus, from the Zuni point of view, man is perhaps even a "permanent factor" in the universe.

The songs and prayers cited in this essay evidence the Navaho and Pueblo belief that man is indeed a source of the world's value. In ways that perhaps they don't realize, the popularizers of Native American cultures are correct when they say these traditions hold ecological lessons for the Anglo world. The lesson of Navaho and Pueblo traditions is that man need not submit to nature's benevolence and that the human need not be denied in order for man to live harmoniously with nature. "Man," said Santayana, "cannot attain this happiness by conforming to that which is hostile to himself; he can thus attain only his dissolution. By using what is hostile to himself for his own ends, as far as energy extends, he can make an oasis for himself in Nature, and being at peace with himself, be at peace with her." 26 Through a transforming and controlling spiritual energy, through that human creativity corresponding to the creativity of the universe, these people have assured themselves of nature's benevolence and thus of man's survival. They have lived in peace with nature and with themselves. "From the middle outward breath is breathed." Through the human spirit, man's road is fulfilled.*

* Santayana, Interpretations of Poetry and Religion, 247.

* The research for this article was made possible by a National Endowment for the Humanities Summer Stipend (1974). I wish to thank the library staffs of the Laboratory of Anthropology, Museum of New Mexico, Santa Fe, and the Museum of Northern Arizona, Flagstaff, for their kindness and assistance during the summer of 1974. 
and concluded that assimilation into a European culture would not only be good for Indian people, but would be what they come to desire.

The central fact about American Indian people today is that they are enormously diverse in culture, attitude, and personality, and that four hundred years after Hakluyt and Peckham, large numbers are still not interested in assimilation. A good Indian show would be one which stressed the continuing vitality of Indian life, and made clear that we must learn to speak of cultures, and not culture. Even using broad regional terms implies a distortion; it implies that reservation people, for example, have a great deal in common, which is not necessarily true. Indeed, even within a single tribe on a single reservation it is very difficult to generalize. Years of unsolvable problems and constant pressure from outside the tribe have almost invariably produced extreme factionalism. Even anthropologists speaking of the same tribe often sound like the proverbial blind men and the elephant. One anthropologist has been working with informants who are comfortably assimilated and regard their tribal ties in much the way that other Americans think of their ethnic identity. Another knows people who live in a "modern" way, but still feel markedly "tribal"; they use the economy of the nation as a resource to support a life of traditional values, customs, and relationships. A third, working with the same tribe, has made it a point to study people still relatively isolated from the artifacts of modern society. Each feels that the others' group is not "typical."

There is, however, a rough consensus among Indianists that American Indian people and their cultures are not "vanishing." Some say, indeed, that the population of tribally-oriented and traditional Indian peoples continues to grow at a rate more than rapid enough to compensate for people lost to the tribes through "spin-off." Spin-off means assimilation; the policy of colonial and national governments from the start has been to encourage spin-off; countless thousands of Indian people have been spun-off, but the tribes remain. Moreover, those spun-off have often maintained a more than sentimental tie to the old cultures. Though they may be resented by more traditional kin, they are likely to behave as allies if the tribe is threatened.

As one entered Sacred Circles, one encountered a "reader" on the wall which made the point that there is a great diversity of American Indian languages and language families. It suggested that the show to come, while emphasizing the aesthetic accomplishment of Indian people, would also educate the viewers, giving them some sense of the multiplicity of distinct native cultures which is characteristic of our land. But that sign, alas, was all there was; the idea was not picked up and developed, and listening to what visitors said made it evident that many of the errors of the last 400 years are still afloat in our society. Presumably people going to a show of this 
sort do so because of a friendly interest in American Indian peoples. And despite a bad press, 223,000 visitors came. But they came knowing very little, and went away without having learned any more than that Indian people have produced some beautiful objects. I confess that I came away from my first visit to Sacred Circles angry and hurt. It seemed to me criminal that so large an Indian event could be staged without an effort being made to pass on to potentially sympathetic visitors the facts Americans need to understand at this critical point in Indian-government relations. Now, perhaps an art show should not be expected to make social, cultural, and historical points; perhaps, indeed, museums never have been very effective pedagogically.

Conversations with $\mathrm{Mr}$. Coe made clear that his understanding of the complexities of contemporary American Indian cultures is sophisticated and first-hand. He knows many American Indian people, understands both cultural differences and intra-tribal factionalisms, and wanted his show to be of service to Indian communities. Even those visitors who elected not to purchase the catalogue were given a flyer as they entered; it contained a floor-plan of the exhibit, a map of North America showing the historic location of tribes with broad regions labelled, photos of a few items on display, and a few hundred words of prose, including this paragraph:

The dominant feature of the history of North American Indian culture has been the crushing effect of the white man. In an exceedingly short space of time, tribes lost their homelands, their livelihood, their numerical strength and the freedom to lead their life as they pleased. Just as the classic Indian speeches by tribal leaders such as Chief Joseph and Black Elk record their anger and frustration at this invasion, so do the drawings of the glorious adventures which are crowded on the Reservation Period costumes and ledger books. In spite of these adversities of the past, in many areas the core of traditional Indian thought still governs the tribal way of life. The intention in choosing examples of work by living artists for this exhibition was to demonstrate the survival and renewal of ideas and forms which are wholly native.

Despite implications that the "diminishing" goes on, that is not a bad statement, especially in that it suggests continued tribal vitality.

Similar points are made in the catalogue, for the show itself was designed not to teach history or anthropology, but to impress the viewer with the beauty of Indian art and the continuity of Indian artistic traditions. The traditions in which $\mathrm{Mr}$. Coe has the strongest personal interest are those which link certain West Coast tribal groups to the Orient. He has an interesting article, "Asiatic Sources of Northwest Coast Art," in the catalogue of the Walker Art Center's 1972 American Indian Art: Form and 
Tradition, ${ }^{1}$ in which he presents parallels between objects produced by such Northwest coast groups as the Kwakiutl, Haida, and Tlingit, and Chinese and Japanese sculpture. He also lectured on this subject at the Nelson during the run of Sacred Circles. Although this is a scholarly issue, far removed from the pressing concerns of Indian people, in fact any stress on the antiquity and continued vitality of tribal cultural characteristics is important to many Indian people; pride in tribal culture was a clearlyarticulated principle in numerous cultures, long before other American minorities discovered it.

This point - that one can see continuities in art work - was so important in Coe's mind that it defined the temporal scope of the show, 2000 years. But it came across so weakly that many viewers were completely unaware of it after seeing the show. To understand how this can be, we need to know a little about the museological context of Sacred Circles.

One prime shaper of Sacred Circles was, of course, the enormously successful "Chinese Exhibition," "The Exhibition of Archeological Finds of the People's Republic of China," shown in the Nelson Gallery in 1975. The consensus then was that the Kansas City mounting was the best that the show had recaived. Although Chinese insistence on precisely what could be said, and in what terms, made that show a pedagogical muddle, it drew people by the hundreds of thousands, and clearly was the sort of thing Mr. Coe had in mind. (The objects in that show were not, by and large, as beautiful as those in the Nelson's own superb oriental collections, though they were displayed with great drama. The show's main importance was in the remarkable historical implications of some of the archeological finds, though plainly the general viewer missed that point - ironically, the artistic impact of that archeological show was at least as great as that of the "purely artistic" Sacred Circles.) Mr. Coe made use of many members of the same staff, including Robert K. Martin, project director of both shows. He makes no secret of the fact that he had the parallel in mind. The featured piece in this show, given dramatic mounting at about the same point in the show at which the famous flying horse of the Chinese exhibition was shown, is another flying horse, an energetic Sioux wood carving (see Figure 1). ${ }^{2}$

$\mathrm{Mr}$. Coe's personal interest in the field made his own perceptions a second important influence on the show. As the son of a pioneering collector of French Impressionist art and of African sculpture, Ted Coe was even as a youngster used to visits from dealers; he'd been exposed to Covarrubias'

${ }^{1}$ (Minneapolis, 1972), 85-91.

${ }^{2}$ The Denver Art Museum has another Sioux flying horse, a catlinite pipe bowl, reproduced in Norman Feder's American Indian Art (New York: Harold N. Abrams, Inc., n.d. [1965?]), plate 42. 


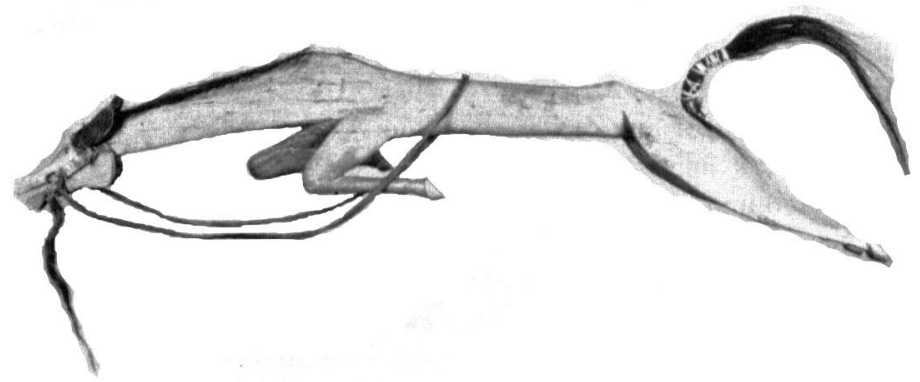

Figure 1: The "Flying Horse": A Sioux effigy of a wounded horse, and a centerpiece of Sacred Circles. "No other complete equestrian sculpture is known to exist." (Catalogue, p. 168).

work, ${ }^{3}$ and already knew Julius Karleback, an art dealer who was into ethnology, before he began collecting Indian art. The start came while he was still a graduate student at Yale in 1955; he bought a Haida totem pole model, and not long afterwards, traded it for a larger model which is exhibited in Sacred Circles. When asked why he had begun collecting American Indian works, Coe spoke of Northwest coast design systems and the fact that his father was a trustee of the Cleveland Museum. He said that he responded to the "sophisticatedly barbaric splendor" of the works he saw - in other words, this was a matter of taste.

Coe is sensitive to the fact that the show might become more a landmark in taste-making and in the art market than in the history of Indian-white relations. The market for works of "conventional" art puts terrible pressures on museums and art-lovers; art-as-investment confuses viewers and places

${ }^{3}$ See Miguel Covarrubias, The Eagle, the Jaguar, and the Serpent: Indian Art of the Americas/North America: Alaska, Canada, the United States (New York: Alfred A. Knopf, 1954). 


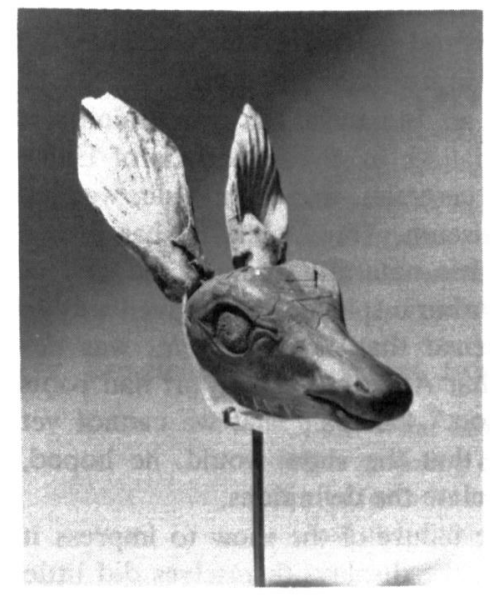

Figure 2: Deer Mask: One of a group of fragile pre-European-contact objects found in the Key Marco shell mounds in 1895 .

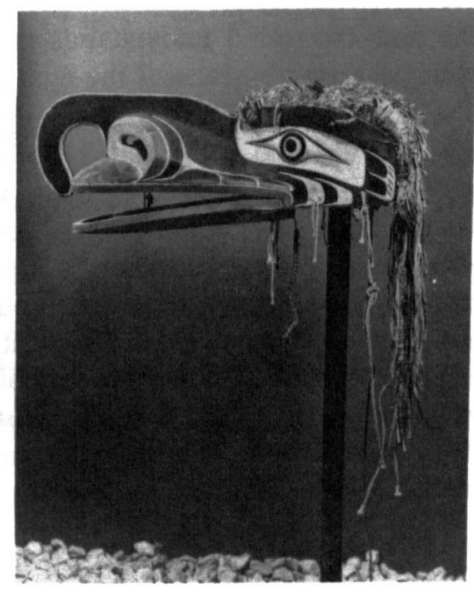

Figure 3: Kwakiutl Mask: Dating from about 1915 , this mask was carved by Willie Seaweed, and was used in connection with a ceremony involving ritual cannibalism.

the purchase of modest works by known artists out of the reach of collectors of moderate income. The development of heavy market pressure for Native American art could produce a situation even worse. I suppose that it will enrich dealers and even some tribal people, but it will probably becloud and confuse an already unclear cultural situation: Western aesthetic notions are alien to tribal traditions, and have little to do, generally, with the uses for which art objects were produced. Add to that the obscure criteria for market value and one has a recipe for chaos (see Figures 2 and 3 ).

Mr. Coe told me of a Kansas Potawatomi friend, who, after the catalogue was printed and the show essentially complete, offered Coe access to the beautiful things he owned. Coe politely declined, because he thought there was no way to add more to the show. At the last minute, learning of an open space in one of the rooms, Coe called his friend, who led him to an out-building at his spread near Mayetta, Kansas, where Coe had his pick of what he saw as a priceless collection of beautiful objects which should 
not have been stored so casually. Coe, in other words, because he is familiar with the world of art collecting, must of necessity see these objects from a perspective different than that of his Indian friends, even if, as well may be the case, the friend understands their potential market value. Coe has high ethics and standards: will the next person in a similar situation?

Coe sees himself as an "outsider," not an Indianist. His own training is art-historical and curatorial. He also specializes in several periods of European art, in Renaissance bronzes, and in ceramics, and after Yale, worked for a time at the Victoria and Albert Museum. Thus, while he has grown more sophisticated in Indian matters, he has naturally retained the cast of mind of a trained art historian, though "barbaric splendor" has given way to more subtle issues. This is how it happened that Sacred Circles was designed to prove an art-historical point: "that American Indian art had roots way back, and meaning for the future, too." Coe said that we cannot yet fully define these artistic traditions, but that the show would, he hoped, encourage the scholarship needed to formulate the definitions.

Since this was clear in Coe's mind, the failure of the show to impress it on viewers is interesting. To tell the truth, the displays themselves did little to make the point. I can't help thinking that good labels would have done the job: "Look how this motif from the third century (or whenever) is still present in that trade item made in the nineteenth." But even if they had, the force of conventional wisdom about American Indians would have kept many visitors from understanding. ${ }^{4}$ Conventional wisdom perhaps affects "art officials" as well as their customers.

The idea of continuity of traditions certainly cannot be news to American Indian people, but it is an important point and one worth making, and has strong cultural implications. Yet at the very tag end of the show, when one walked by the beautiful, very old-fashioned photographs of Indian people by Edward Curtis, ${ }^{5}$ one encountered one entitled, "The Vanishing RaceNavajo," and nothing was done to put the absurd title in context. I heard viewers sighing in agreement, and talking about the pity that all of this was gone, lost, and so forth. The show, in other words, inadvertently re-

\footnotetext{
'A viewer who had this point in mind would have seen stylistic connections between work done at different periods. If he consulted his catalogue diligently and noted carefully the dates of related objects on display, he would have seen continuities. But in four long visits to Sacred Circles, and numerous conversations with visitors, I heard not a word to indicate that anyone perceived the continuities the show was supposed to stress.

${ }^{5}$ Yet another extraneous aesthetic rears its head in these photos, in which Curtis tried not only to record Indian faces, figures, and scenes, but to produce "art" with his camera. One feels the old debate about whether photographs can be "art" (if they look like paintings?), or whether photography should stop imitating painting and develop its own aesthetic.
} 
inforced the most terrible misconception of all. One thinks of the elegiac sadness of romantic poets who thought they saw the ends of races Emerson's,

The over-God
Who marries Right to Might
Who peoples, unpeoples-
He who exterminates
Races by stronger races,
Black by White faces,-
Knows to bring honey
Out of the lion....

or Longfellow's last stanza from "The Jewish Cemetery at Newport,"

But ah! What has been shall be no more!

The groaning earth in travail and in pain

Brings forth its races, but does not restore,

And the dead nations never rise again.

The extinction of the Blacks, the conversion of the Jews, and the assimilation of the Indian have been confidently expected for eons. Don't hold your breath.

Clearly Mr. Coe did not want the show to leave the impression that Native America was a terminal case; his point was continuity and continued vitality - ancient objects dug from Ohio mounds, colonial-epoch treasures brought back from Europe, and contemporary Pomo artists weaving baskets in the Nelson's huge entrance hall. Indeed, he made a point of stressing the difference between Sacred Circles and the show which Norman Feder did at the Whitney Museum in the early seventies. Whereas Coe used two thousand years to stress continuity, Feder limited his to two hundred. Feder's idea was that by focusing on the two hundred years between first white contact and recent Indian art, both of which he eliminated from the show, he would be able to minimize the aura of archeology on the one hand and the influence of the art market on the other. He wanted to leave out craft material, and stress just art - though he admitted that it's very hard to draw lines between art and craft. The result is that his show was very heavy in sculpture; it downplayed textiles and other "crafts." It is especially difficult to distinguish art from craft when dealing with traditional societies. Almost the central point to be made about the way in which objects are produced is that they are not made by people living in the specialized cubbyholes in which modernized societies place them. The Navajo man who makes the sand painting in a traditional situation (perhaps because someone has brought a sick child to him) is at once artist, crafts- 
man, magician, shaman, physician, scientist, and perhaps some other things as well. When a Plains Indian wanted his buffalo-skin tent to bear drawings of heroic exploits, he turned not to a "tribal artist," but rather to the warrior who had experienced the exploits to draw them. And which is more "crafty," or more "arty," a figure carved for purely religious purposes or a pipe bowl carved in the likeness of a buffalo? Neither is art-for-art's-sake; the religious object is intended to be as functional as the pipe; indeed, the pipe, too, has religious significance.

Coe says that Feder is far more an Indian-art specialist than he is, but, as this problem of art vs. craft suggests, there are contradictions in Feder's work, too. They seem inherent in crossing disciplines.

Feder wrote in American Indian Art, "A short twenty-five years ago, the only place where primitive art could be seen was in the usual culturally oriented exhibits of the major natural history museums. Today, such museums have begun to display specimens with an emphasis on their artistic qualities. . . ." American Indian Art," he continues, "is riding on the popularity bandwagon of a widespread interest in primitive art from all regions of the world." His use of that word "primitive" in 1965 shows how rapidly attitudes have changed; its use today would seem insensitive.

Feder also wrote,

Another factor is that the American Indians are gradually being assimilated into American society. This is partly due to government programs of termination and relocation, and partly to an inevitable process of acculturation which began with the Indian's first contact with Europeans. . . . At this point we can look into the future and foresee the final stage of this process: almost complete acculturation will have taken place, resulting, of course, in the complete disappearance of the native arts. ${ }^{6}$

We have already seen how common is this assumption that total assimilation is imminent. Elizabeth Clark Rosenthal put the matter of assimilated traits and tribal identity best:

A professional social scientist . . was studying kinship and, at considerable trouble, managed to get to a remote corner of one of the larger Indian reservations. He was delighted to find what he had been looking for: a family in which the children still called their mother's sister "mother." I was not surprised. I had spent the night before in a nearby city with old friends. They have lived there ten years, own their home, had young children. Their children called their mother's sister "mother" too.?

' Norman Feder, Two Hundred Years of North American Indian Art, with a preface by John I. H. Baur (New York: Praeger, 1971), is the catalogue. See pp. 2, 21 .

7 "Culture and the American Indian Community," in Stuart Levine and Nancy O. Lurie, eds., The American Indian Today (Baltimore: Penguin, 1971), 82-89, p. 86. 
Indian groups have "borrowed culture" from one another at least since our first records of them, and from Europeans since first they met them. A person whose culture includes borrowed elements is culturally richer, not a cultural ruin. Borrowing does not equal assimilation. Feder seems to know most of this; in one passage, even while he speaks of a very gradual assimilation, he stresses how naive it is to look for purity when tribes have always borrowed. Given his apparent sophistication, then, why does Feder make the usual sad statements about the Vanishing Redman? For certainly even in 1865 , let alone 1965, no authority should have spoken as foolishly as Feder did when he wrote that the collecting of Indian arts is "feverish, a last effort to obtain whatever is left of the old culture before it completely disappears." The two main errors of the sixteenth century writers are still present: Indians are readily assimilable and there is an Indian culture. A passage a couple of pages later makes clear that he really does know more than Hakluyt and Peckham did when he writes, "Each tribal group-in some instances even each division of a tribal group-should be considered as a separate entity."8

I did not, then, feel that there was any reason for anger at a museum curator whose work displays this sort of ambiguity. Both Feder and Coe are essentially aestheticians and art historians, and it is difficult for them to move outside of the formulations of the disciplines in which they are trained. We are told that specialization and compartmentalization are characteristic of modernized societies; art specialists are different than culture specialists. Even though they may have sophisticated anthropological and cultural information, when they talk about art objects, they make the noises which art historians and critics make. For example: Feder, in his catalogue to the 1971 Whitney show which, like Sacred Circles, was designed to stress art, not culture, showed amply that he knew that the artist and the craftsman are never two different people in tribal cultures. Yet in the same catalogue he attempted to make that distinction.

That Feder is essentially an aesthetician is clear enough in a passage such as the following, in which he describes his teaching method.

As part of my duties at the Denver Art Museum, I often give seminars on African art to groups of art students. One of the things I frequently ask the students to do is to experiment with a lump of clay and use variations on the human face by intentional distortion. I encourage the students to let their imaginations run wild-to extend a nose, diminish an eye, or misshape an ear. Then during the course of the seminar, we look at African masks and marvel at the fact that African artists produce almost every distortion that we could imagine. It is a rare occasion when a student comes up with a totally new idea.

'American Indian Art, 22, 25, 57-58. 
The point I want to make here is that the Alaskan Eskimo, occupying a much smaller land area, has developed as much imaginative distortion as all of Africa. ${ }^{9}$

The aesthetics implied in that paragraph is far removed from any tribal ideal. Feder, who sounds like an excellent teacher, values innovation, creativity, diversity, all good values, but values which are specific to our kind of culture, and not to most traditional cultures. Characteristically, the member of the tribe who produces an object tries to make it correctly, so that it will have the right powers, perhaps. Or perhaps he produces it under the dictation of a supernatural spirit. At any rate, it is produced from an aesthetic entirely alien to the one presented in any Western pedagogical situation.

The odd ambiguity shows up in discussing other issues as well. Sacred Circles, like the other show, included some objects which were produced for sale or trade to whites. Feder and Coe handle this comfortably and intelligently: goods produced for trade can be, and very often are, based on legitimate tribal traditions; the quality of workmanship may be fully as high as in objects intended for use within the tribe. Similarly, new and nontraditional materials are no problem, either. One thinks once again of Rosenthal's comments on the ability of tribal people to absorb whatever they want from cultures around them. We now think of the elaborate feathered headdress as characteristic of Plains Indians in general; as a matter of fact, that is a borrowed item, which spread from one tribe to another because it was admired. We think of the beadwork of numerous different tribal groups as being characteristically "Indian," but those beads, of course, are a trade item, which came from non-Indian traders.

But it is characteristic of specialists from time to time to forget these things, and to turn to statements as old and as wrong as those of Peckham or Longfellow. Feder, for example, concludes in his Whitney catalogue, "There has been a slow, continual process of acculturation in most Indian groups, and this will lead eventually to complete assimilation, with the resulting disappearance of traditional Indian art forms. The trend seems to be toward the development of new art forms utilizing the age-old Indian heritage, but based on non-Indian techniques and materials." 10 That sounds as though tribal arts in the past were static, and one people did not borrow from or influence another. A technique borrowed from a culturally distant tribe is as alien as one borrowed from non-Indians. Neither necessarily destroys culture nor dilutes aesthetic quality (see Figure 4). I am certain that Mr. Feder knows this.

\footnotetext{
'Two Hundred Years . . . II.

"Ibid., 22.
} 


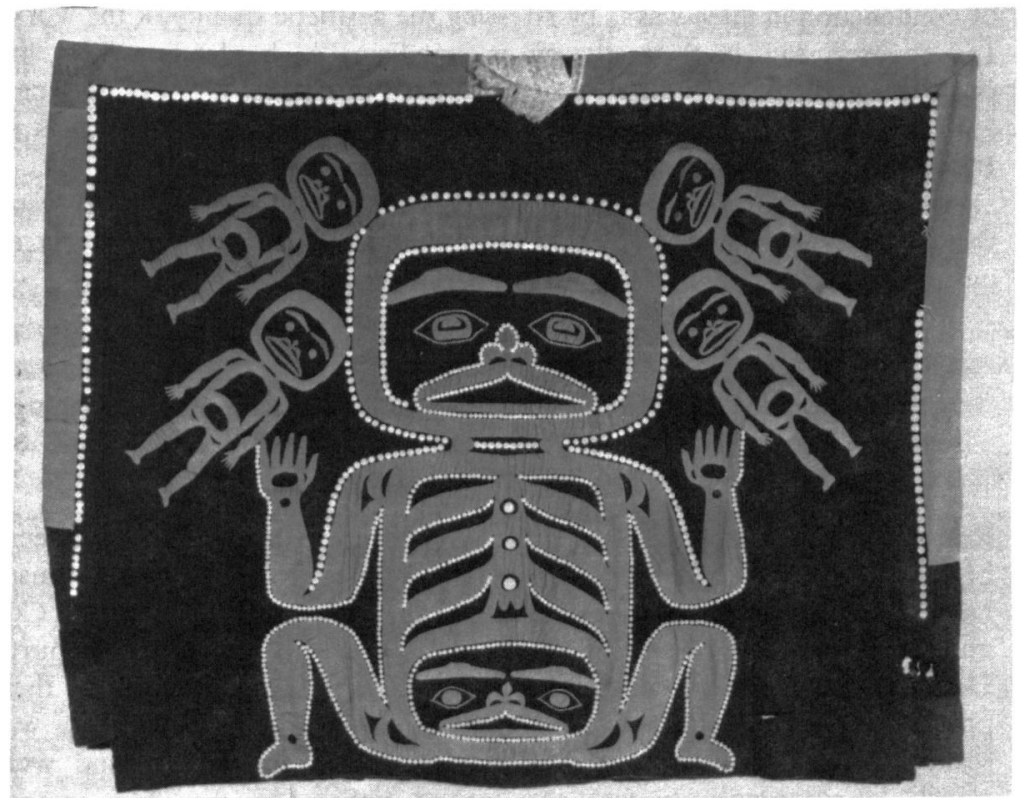

Figure 4: Tsimshian Button Blanket: Often made of Chinese trade buttons, trade blankets and felt, such works illustrate the point that contact with alien cultures need not extinguish indigenous creativity - it may indeed stimulate it. This dates from the early 19th century.

Mr. Coe's idea of stressing the continual vitality of Amerindian cultural traditions, whether or not it came across effectively in Sacred Circles, is important if we are to understand the exhibit as an artifact of our own civilization. If one wants to enhance the prestige of a new field, this is one way to do it. As the spectator contemplates the age of the objects, his respect for the subject grows; he is ready to respond favorably to experts who can point out continuities for him to understand and "appreciate." I do not mean this facetiously; it is one of the ways in which tastes develop in our society; the process is, in my mind, a good thing. From the point of view of the discipline of art history, what is going on when one establishes the temporal pedigree of a motif of the sort one sees in Amerindian art is an important part of the "condonation process" which establishes which works or genres are to be considered "important." It is nice to have this respect developed for works by Indians, but we should understand that the development reveals the workings of "our" culture, not "theirs." Sacred objects scarcely need such condonation. Sacred Circles helped this process 
of condonation in three ways: by stressing the aesthetic quality of the works (as opposed, say, to their efficacy as "medicine"); by lending them the prestige and dignity of a major art (as opposed to natural history) museum; and by stressing the continuity of traditions to suggest that there exists in Indian art a "discipline" worthy of study and appreciation.

Mr. Coe sees his work as part of a recent effort by museologists to teach the public to see American Indian objects as works of art, not merely as cultural artifacts. Beth Dillingham put it this way:

Until recently, American Indian art works were exhibited in museums of natural history, beside dinosaur bones, insect displays, and stuffed animals. Art museums, on the other hand, tended to concentrate on the paintings, sculpture, pottery, textiles, etc., produced by the "higher civilizations" of Europe and Asia and the Mediterranean area."1

Rene d'Harnoncourt and Frederic $\mathrm{H}$. Douglas are considered the pioneers of the movement to get Indian art out of what were felt to be the musty halls of anthropological museums and into the art museums; both $\mathrm{Mr}$. Coe and the authors of other books on the subject regard the d'HarnoncourtDouglas show and book, Indian Art of the United States of 1941, as their precursor. But given that background, the appearance of Sacred Circles was disappointing. The show was drab-looking. Walls and background were mostly tan or brown. In fact, this looked rather like the older science museums the show was supposed to be different from. Certainly there was nothing in the show as elegantly mounted as the Nelson's own installation of items from its collection of American Indian art which were not included in Sacred Circles. Those elegant galleries were deserted during Sacred Circles, but their appearance shamed anything in the show. ${ }^{12}$

Restrictions placed on the Kansas City staff by European museums in part accounted for the drabness; the Nelson was allowed to show certain objects only if the illumination were kept below 100 lumens, which is dim by American museum standards. Numerous other forces and intentions shaped the final form of Sacred Circles. Coe had to work through a British organization, and while cooperation was good and the situation basically amicable, there were differences of perception. Then, too, an important purpose of the show was to bring together for the first time since the earliest contact with Europeans a number of important sixteenth, seven-

\footnotetext{
"'The Recent Past," in Art of the First Americans (Cincinnati: Cincinnati Art Museum, 1976), 14.

${ }^{12}$ Besides the colors in the art works themselves, the only touch of color used consistently throughout Sacred Circles appeared in the large color photographs on the walls; that in the first room, for example, was an aerial view of a spectacular-serpent mound.
} 
teenth, eighteenth, and nineteenth century objects which had been carried to Europe. One has to remember that much Indian art is impermanent. In many cases our only examples of certain objects from before quite recent times are in European museums or collections. Mr. Coe undoubtedly felt that he should show such objects because they were old, beautiful, and important, whether or not they contributed to making his point about the continuity of artistic traditions. Coe also sees the show in terms of the formidable problems he faced in borrowing, shipping, insuring, and placating. Even considering these difficulties, other museologists have been critical of the show's bad planning, bad labelling, and bad cabinetry. It is true that certain types of items can be seen better in book reproductions such as Feder's American Indian Art or in the Nelson Gallery catalogue of Sacred Circles. ${ }^{13}$

A complaint I heard repeatedly was that Sacred Circles was not, for all the international cooperation and massive funding, qualitatively superior to other shows much more modestly endowed. The Cincinnati Art Museum show, for example, mounted in 1976, was also arranged geographically by culture group and also contained works of great beauty. Millard F. Rogers, Jr., the Cincinnati director, said that when he explored his Museum's storage rooms on becoming director, he found "about 50,000 accessioned objects" of American Indian art. ${ }^{14}$ The number of first-rate objects scattered in collections around the nation is remarkably high. I had noted with pleasure in going through Sacred Circles that Coe had made use not only of his own and the Nelson's holdings, but of things from large and small museums in this part of the midwest, such as the Jocelyn in Omaha, the Kansas City Museum, and the St. Joseph Museum. The holdings of these places are very substantial, and the quality high. I visited several to see what they were doing in conjunction with Sacred Circles. The Kansas City Museum is currently being refurbished, and had ready for the Sacred Circles period some handsome rooms illustrating particular tribal lifestyles. Up on the top floor its staff had done a brilliant thing in putting their entire Indian collection in "open storage" - hundreds of beautiful objects set out in old cases. They weren't labelled (though sometimes one could read the storage tags) but spoke eloquently anyway: even if one had no idea of which tribe

\footnotetext{
${ }^{13}$ Objects are sometimes shown in distortedly bright colors in these books; the color plates look pretty and intense, but when one holds them up next to the objects themselves, one sees that the colors are not true. Still, visibility was so bad in Sacred Circles that some things could be studied best from books. I felt this way in particular about catlinite pipes collected from plains tribes. The labels were hard to read, too-dimly typed, behind glass which often reflected images.

${ }^{14}$ In the "Foreword" in the catalogue for this show. Art of the First Americans, p. 5. The show was done entirely from Cincinnati holdings.
} 
produced something, one could see a dozen gradations and variants of design motifs, and thus get a good sense of continuity of tradition. It was homely as sin, but troublingly effective. Visitors seemed to feel as though they were rummaging through this museum's attic, and they were more excited than those at the Nelson. Since many had not known about the special Indian show, but just came in off the street (most brought children to this old natural history museum), that excitement and perception were especially impressive.

My doubts about which museum practices produce which results grew ominously after a visit to the charmingly amateurish St. Joseph Museum. Its Indian collection is outstanding, and it has always been worth a visit. In conjunction with Sacred Circles, it too had gussied itself up with some new displays, the artifacts mounted in shallow cases directly on monochrome sketches of historic Indian people in characteristic settings. Viewers could tell both "how pretty" and "what it was used for." Coe, like the organizers of art museum shows since 1941, had deliberately wanted to force visitors to see objects as art; one wondered after St. Joseph whether seeing them as artifact, too, really diminished them in any sense.

Although one worries that some of the resentment which Indian people now sometimes feel against anthropologists will be transferred to art historians, and although I heard many specific complaints from Indians about the show, certainly most of the many Indian people who travelled often great distances - to see Sacred Circles liked it: even if somewhat overwhelmed by its size, they spoke with pleasure at the beauty and richness of Indian artistic production. Indian people self-consciously concerned with arts and crafts may, almost by definition, be people more comfortable in their dual relations with tribe on the the one hand and ecumene on the other. Interest in the show also seems to indicate interest in tribes other than one's own, and, though "pan-Indian" feeling is certainly not new, it is far from a dominant attitude. Pan-Indianism is certainly growing stronger, however, at least partially because "Indian" is easier for citizens of the ecumene to understand than the complex reality, and hence politically more effective. Certainly an unintended side effect of Sacred Circles is to promote fellow-feeling among tribal peoples from culturally and geographically disparate backgrounds.

A number of the things said in this discussion of Sacred Circles as an artifact of our culture can be summarized in terms of those puzzling contradictions in the movement to show Indian art as art. In the big show itself, I find myself recurring to that Curtis photograph: a picture which Curtis thought indicated the end of the line featured in a show designed to stress continued vitality, and organized by the same man who wrote, 
The aim of Sacred Circles is to demonstrate that American Indian art is worthy of being shown as belonging among the great artistic traditions of the world. It is time that credit is given to these peoples for their own creative ability. The continuity of Indian art presented to a North American audience through such an exhibit could be enormously beneficial, giving the art of the First Americans the prominence it so richly deserves. ${ }^{1 .}$

I would suggest that the unexplained contradiction was the result first of the size and complexity of the project, and second of the strength of disciplinary boundaries. Mr. Coe spoke of aspects of Sacred Circles which were beyond his control. The title itself: he had wanted to call the exhibit, "The Medicine Wheel" to stress the persistence of circular design and its relation to magical views of the cosmos in numerous cultures over time. But that seemed obscure to British colleagues. He had visualized leading the viewer through "Dante-esque circles"; he was turned down by the Ashmolean on his request to bring a key work from the London show to Kansas City; he endured crises at the airport, diplomatic pressures, problems with mounting, lighting, cabinetry, security, handling, and shipping; he was unable to control the catalog - perhaps if he had, his main points would have come through more clearly and to more people. But in part the contradiction is the result, too, of the fact that we're not trained to connect ideas from such disparate fields. The show was designed to emphasize the beauty of Indian achievement; the Curtis photos are beautiful, too. But the show was to emphasize continued vitality, also, and the photo says that Indian peoples had come, decades ago, to the end of the trail. There were too many categories to keep track of, and too many pressures on the boss as well for him to retain the close control it would have taken to insure that Sacred Circles made a more pointed and coherent statement. Ideally, the photo should have remained where it was with a label pointing out that it came from a period of terrible times for many tribes, a period which coincided with the high-water mark of racist thinking in the country, and that the viewer who wants to see how "vanished" the red man is need only walk a few yards into the Nelson's entrance hall to talk to some vigorous survivors.

Certainly, one can't really find a cause for anger at Mr. Coe; without him there would have been no show, no awed European response to the wonders of aboriginal artistic production in North America, no convergence of Indian people on Kansas City to discover new riches in a past perhaps, at least in some aspects, surprising to each.

${ }^{15}$ Ralph T. Coe, "Major Exhibition of American Indian Art," Archeology (Mar. 1977 ), 124-28, p. 128. 


\section{NOTICE}

It has come to my attention that I used a number of brief passages and descriptive phrases from Louis Harap's The Image of the Jew in American Literature (1974), without acknowledgment or quotation marks in my American Quarterly article, "American Anti-Semitism: A Reinterpretation," (Summer 1977, pp. 166-81). This was done by me inadvertently and was careless and inexcusable. I hereby express my regrets to Dr. Harap, the author of that important book, and to the American Quarterly.

Sincerely,

Michael N. Dobkowski

Assistant Professor of Religious Studies Hobart and William Smith Colleges

\section{AQ EDITORIAL BOARD}

The American Quarterly announces openings on its editorial board. We urge all regional chapters of the American Studies Association, through their officers, to suggest individuals to be considered for nomination to the editorial board. We hope to encourage selection of board members from the widest possible body of scholars. In their suggestions, regional chapters should consider areas of scholarship they wish the Quarterly to encourage. All scholars suggested should have demonstrated intellectual excellence in their publications. Regions should provide vitae. Deadline for consideration is July 15, 1978. 